\title{
PENGARUH IMPLEMENTASI SISTEM MANAJEMEN KESELAMATAN KONSTRUKSI TERHADAP KINERJA PROYEK PEMBANGUNAN FLYOVER (STUDI KASUS: FLYOVER SULTAN AGUNG TANJUNG KARANG)
}

\author{
Fitri Yalina ${ }^{1}$, Tia Sugiri ${ }^{2}$ \\ ${ }^{1,2}$ Program Magister Teknik Sipil Pascasarjana Universitas Sangga Buana \\ ${ }^{1}$ korespondensi : f.yalina@yahoo.com
}

\begin{abstract}
The Construction Safety Management System (CSMS) is a part of the management system for construction work in order to ensure the safety of a construction work. In Indonesia, the guidelines for the CSMS is regulated in the Regulation of the Minister of Public Works and Public Housing Number 21/PRT/M/2019 (Peraturan Menteri PUPR No.21/PRT/M/2019). This research was conducted to find out how the CSMS was implemented in the Sultan Agung Flyover construction project, what is the dominant factors of the CSMS implementation and how those factors influence the project performance. The project performance in this research is based on the time efficiency of the work, the quality of the final results of the work, and the correlation between the CSMS implementation factors. The research method used for this thesis was the descriptive verification method with quantitative approach. The data analysis on the Flyover construction project was carried out by compiling and analyzing the results of interviews that has been conducted, observing the project site, and evaluating the CSMS data and literatures for the supporting data. SPSS V25 was used for analyzing the questionnaire results. The results of this research showed that the CSMS planning for the Flyover construction project was in the quite good category, while the CSMS activity components has been implemented thoroughly. From this research, there are two dominant factors that can be obtained, they are X4 Variable (The Operations of Construction Safety) and X5 Variable (The Evaluations of The Construction Safety Performance). These two dominant factors have a significant influence on the project performance. The X4 variable has the effect value of 7,743, while the X5 variable has the effect value of 3,61. In addition, the implementation of the CSMS factors has a really strong correlation between them and brought a positive influence on the workers and related stakeholders and made them realize the importance of occupational safety and health in a construction project.
\end{abstract}

Keywords: Implementation, CSMS, Flyover, Construction project performance

\begin{abstract}
ABSTRAK
Sistem Manajemen Keselamatan Konstruksi (SMKK) adalah bagian dari sistem manajemen pelaksanaan pekerjaan konstruksi dalam rangka menjamin terwujudnya Keselamatan Konstruksi [1]. Pedoman SMKK di Indonesia diatur dalam Peraturan Menteri Pekerjaan Umum dan Perumahan Rak yat Nomor21/PRT/M/2019.Penelitian ini dilakukan untuk mengetahui implementasi SMKK pada proyek pembangunan Flyover Sultan Agung, faktor-faktor dominan implementasi SMKK dan besarnya pengaruh faktor-faktor tersebut terhadap kinerja proyek berdasarkan efisiensi waktu, biaya dan kualitas hasil kerja, serta korelasi antara faktor-faktor implementasi SMKK tersebut.Metode penelitian yang digunakan adalah deskriptif verifikatif dengan pendekatan kuantitatif. Sebagai analisis data implementasi SMKK pada proyek pembangunan Flyover dilakukan dengan menyusun dan membahas hasil wawancara, observasi di lokasi proyek, evaluasi data-data SMKK yang tersedia serta studi kepustakaan sebagai data pendukung, sedangkan untuk analis data hasil kuesioner digunakan bantuan program aplikasi SPSS V25. Hasil penelitian menunjukan rencana penerapan SMKK pada proyek pembangunan Flyover termasuk dalam kategori cukup baik. Komponen kegiatan pelaksanaan Sistem Manajemen Keselamatan Konstruksi (SMKK) telah dilaksanakan secara menyeluruh. Untuk hasil analisis data diperoleh 2 (dua) buah faktor dominan yaitu Variabel X4 (Operasi Keselamatan Konstruksi) dan Variabel X5 (Evaluasi Kinerja Keselamatan Konstruksi) .Faktor-faktor dominan tersebut berpengaruh signifikan terhadap kinerja proyek. Untuk variabel X4 berpengaruh sebesar 7,743 dan variabel X5 berpengaruh sebesar 3,61. Selain itu korelasi antara faktorfaktor implementasi SMKK memiliki hubungan yang kuat.Implementasi SMKK membawa pengaruh positif bagi pekerja dan stakeholder terkait guna menyadari pentingnya keselamatan dan kesehatan kerja bagi pelaksanaan proyek konstruksi .
\end{abstract}

Kata Kunci: Implementasi ,SMKK, Flyover, Kinerja proyek. 


\section{PENDAHULUAN}

\section{Latar Belakang Penelitian}

Sektor konstruksi memainkan peran strategis dalam pembangunan nasional. Selain menjadi pendorong dan bagian dari kegiatan perekonomian, kinerja sektor konstruksi yang berkaitan langsung dengan daya saing infrastruktur nasional juga merupakan pilar sosial, budaya, dan peradaban bangsa. Selain itu dalam hal kecelakaan kerja, industri konstruksi merupakan penyumbang terbesar di Indonesia. Bahkan, berdasarkan data yang dikeluarkan Badan Penyelenggara Jasa Sosial (BPJS) Ketenagakerjaan, industri konstruksi tercatat sebagai jawara nasional kecelakaan kerja dari tahun ke tahun [1]. Walaupun belum ada data yang lengkap dan akurat, tingkat kecelakaan kerja konstruksi di Indonesia diperkirakan cukup tinggi. Industri konstruksi pada tahun 2010 masih menduduki rangking tertinggi kecelakaan kerja yang berakibat fatal $(31,9 \%)$, diatas lapangan kerja lain yaitu industri $(31,6 \%)$, transportasi $(9,3 \%)$, kehutanan $(3,8 \%)$, pertambangan $(2,6 \%)$ dan lain-lain (20\%) [2].

Berdasarkan uraian diatas jelas bahwa keselamatan kerja merupakan hal yang sangat penting dalam industri jasa konstruksi, mengingat industri konstruksi merupakan industri paling beresiko tinggi (high risk) dan yang menempati peringkat utama terjadinya kecelakaan kerja.

Penggunaan teknologi tinggi dan metode pelaksanaan yang tidak akurat serta kurang teliti , penggunaan tenaga kerja, alat berat dan material dalam skala besar disertai dengan waktu pelaksanaan dan lokasi lahan proyek yang terbatas menyebabkan pembangunan Flyover Sultan Agung mempunyai resiko yang cukup tinggi dalam hal kecelakaan kerja. Oleh sebab itu diperlukan suatu model implementasi Sistem Manajemen Keselamatan Konstruksi yang dapat mengatur dan meminimalisasi terjadinya kecelakaan dan sakit akibat kerja pada proyek pembangunan Flyover tersebut.

\section{Rumusan Masalah}

Berdasarkan uraian latar belakang diatas, maka yang menjadi rumusan masalah dalam penelitian ini adalah :

1. Bagaimana implementasi Sistem Manajemen Keselamatan Konstruksi (SMKK) pada proyek pembangunan Flyover Sultan Agung?

2. Apa saja faktor-faktor dominan dalam implementasi Sistem Manajemen Keselamatan Konstruksi (SMKK) yang berpengaruh terhadap kinerja proyek pembangunan Flyover Sultan Agung?

3. Berapa besar pengaruh faktorfaktor dominan implementasi Sistem Manajemen Keselamatan Konstruksi (SMKK) terhadap kinerja proyek pembangunan Flyover Sultan Agung yang diukur dalam parameter efisiensi waktu, efisiensi biaya, dan kualitas hasil pekerjaan? 
4. Berapa besar korelasi antara faktor-faktor implementasi Sistem Manajemen Keselamatan Konstruksi (SMKK) terhadap kinerja proyek pembangunan Flyover Sultan Agung?

\section{Batasan Penelitian}

Penelitian ini dilaksanakan dengan melakukan identifikasi faktor implementasi Sistem Manajemen Keselamatan Konstruksi (SMKK) dengan batasan-batasan berikut ini:

- Penelitian ini dibatasi pada faktor Sistem Manajemen Keselamatan Konstruksi (SMKK) pada proyek pembangunan Flyover Sultan Agung.

- Penelitian didasarkan dari sudut pandang pihak kontraktor proyek pembangunan Flyover Sultan Agung.

\section{Tujuan penelitian}

Tujuan dari penelitian ini adalah sebagai berikut:

1. Mengetahui implementasi Sistem Manajemen Keselamatan Konstruksi (SMKK) pada proyek pembangunan Flyover Sultan Agung .

2. Mengetahui faktor-faktor dominan dalam implementasi Sistem Manajemen Keselamatan Konstruksi (SMKK) yang berpengaruh terhadap kinerja proyek pembangunan Flyover Sultan Agung .

3. Mengetahui berapa besar pengaruh faktorfaktor dominan implementasi Sistem Manajemen Keselamatan Konstruksi (SMKK) terhadap kinerja proyek pembangunan Flyover Sultan Agung yang diukur dalam parameter efisiensi waktu, efisiensi biaya, dan kualitas hasil pekerjaan.

4. Mengetahui berapa besar korelasi antara faktor-faktor implementasi Sistem Manajemen Keselamatan Konstruksi (SMKK) terhadap kinerja proyek.

\section{TINJAUAN PUSTAKA}

\section{Kinerja Proyek Konstruksi}

Kinerja proyek merupakan bagaimana suatu proyek dilaksanakan dengan membandingkan hasil pekerjaan yang telah dilaksanakan secara riil dengan perkiraan yang telah tertera pada kontrak kerja yang telah dirancang oleh kontraktor pelaksana proyek dan telah disepakati oleh kedua pihak, yaitu pemilik proyek dan kontraktor pelaksana.

\section{Sistem Manajemen Keselamatan}

\section{Konstruksi}

Sistem Manajemen Keselamatan Konstruksi (SMKK) adalah bagian dari sistem manajemen pelaksanaan pekerjaan konstruksi yang dilakukan untuk menjamin terwujudnya "keselamatan konstruksi" [3]. Keselamatan Konstruksi sendiri merupakan semua kegiatan keteknikan yang dilakukan untuk mendukung Pekerjaan Konstruksi untuk mewujudkan standar keamanan, keselamatan, kesehatan yang terpenuhi dan berkelanjutan yang menjamin terpenuhinya keselamatan dan kesehatan tenaga kerja keselamatan publik, serta harta benda, material, peralatan, konstruksi dan lingkungan [4]. 
Sasaran Keselamatan dan Kesehatan

\section{Kerja Konstruksi (K3 Konstruksi)}

Sasaran dari program sistem manajemen keselamatan dan kesehatan kerja konstruksi pada lokasi pekerjaan berlangsung adalah karyawan dan tenaga kerja yang berurusan langsung dengan peralatan, material serta lingkungan pekerjaan sekitarnya. Tujuan dan sasaran dalam penerapan SMKK antara lain berikut ini:

1. Mengindari terjadinya kecelakaan kerja.

2. Menghindari munculnya penyakit yang timbul akibat pekerjaan yang dilakukan pada site.

3. Menciptakan lingkungan kerja yang baik dan sehat bagi pekerja.

4. Menghindari terjadinya efek negatif pada lingkungan pekerjaan dan lingkungan sekitarnya yang diakibatkan oleh aktifitas proyek.

\section{METODOLOGI PENELITIAN}

\section{Metode Penelitian}

Metode penelitian yang digunakan oleh penulis adalah metode penelitian deskriptif dan verifikatif dengan pendekatan kuantitatif. Metode penelitian deskriptif digunakan untuk meneliti fakta yang ada secara sistematis berdasarkan objek penelitian, sedangkan metode penelitian verifikatif digunakan untuk menguji hipotesis dengan menggunakan statistik. Lalu hasil penelitian diolah dan dianalisis untuk kemudian diambil kesimpulannya dengan menekankan analisis pada data numerik (angka), sehingga dengan menggunakan metode penelitian ini dapat diketahui hubungan signifikan antara variabel yang diteliti [5]. Kegiatan penelitian ini meliputi pengumpulan data, analisis data, interprestasi data, dan akhirnya dirumuskan suatu kesimpulan yang mengacu pada analisis data tersebut. Untuk metode pengumpulan data digunakan hasil studi pustaka dan studi lapangan (observasi, dokumentasi, wawancara, kuesioner). Teknik pengolahan data hasil kuesioner diukur dengan menggunakan skala likert.

\section{Populasi dan Sampel}

Populasi dalam penelitian ini antara lain manajemen proyek, konsultan pengawas , seluruh pekerja dan stakeholder yang ada kaitannya dengan proyek pembangunan Flyover Sultan Agung. Banyaknya jumlah sampel yang digunakan pada penelitian ini ditetapkan sebanyak 30 orang responden. Dalam penelitian ini digunakan 5 (lima) variabel independen (variabel bebas) yaitu Variabel Kepemimpinan dan Partisipasi Pekerja Dalam Keselamatan Konstruksi (X1), Variabel Perencanaan Keselamatan Konstruksi (X2), Variabel Dukungan Keselamatan Konstruksi (X3), Variabel Operasi Keselamatan Konstruksi (X4), Variabel Evaluasi Kinerja Keselamatan Konstruksi (X5) serta 1 (satu) variabel terikat atau dependent yaitu Variabel Kinerja Proyek $(\mathrm{Y})$.

\section{Metode Pengolahan Data}

Pengolahan data pada penelitian ini menggunakan bantuan program aplikasi SPSS 
(Statistical Product and Service Solutions) Versi 25.

\section{Uji Kualitas Data}

Data primer yang berbentuk kuesioner sebelum dipakai untuk analisa data, perlu terlebih dahulu dilakukan uji validitas dan reliabilitas.

\section{Metode Analisis}

Data yang didapat dari responden kemudian dianalisis meliputi: analisis deskriptif, analisis korelasi, analisis regresi linear berganda, uji asumsi klasik dan uji hipotesis berupa uji $\mathrm{T}$ dan uji F.

\section{HASIL DAN PEMBAHASAN}

\section{Hasil Implementasi SMKK}

Pada proses tahapan ini, diperoleh hasil data penelitian yang berkaitan dengan implementasi Sistem Manajemen Keselamatan Konstruksi (SMKK) pada proyek pembangunan Flyover Sultan Agung.
Hasil data primer akan dianalisi melalui aplikasi program SPSS V25, sementara itu data skunder akan dianalisis dengan cara membandingkan rencana penerapan SMKK di proyek dengan Permen PUPR No. 21 Tahun 2019.

Setelah dilakukan penilaian mandiri atas rencana penerapan Sistem Manajemen Keselamatan Konstruksi pada proyek Pembangunan Flyover Sultan Agung, diperoleh hasil sebesar $72 \%$ dari seluruh rencana penerapan SMKK yang ada. Untuk komponen kegiatan pelaksanaan SMKK sendiri telah dilaksanakan secara menyeluruh. Maka berdasarkan indikator penilaian Peraturan Pemerintan No. 50 Tahun 2012, rencana penerapan SMKK pada proyek Pembangunan Flyover Sultan Agung dikatakan cukup baik. Berikut adalah rekapitulasi hasil peninjauan rencana penerapan SMKK pada proyek tersebut yang dihimpun berdasarkan observasi dan wawancara di lokasi penelitian.

Tabel 1: Rekapitulasi Hasil Tinjauan Rencana Penerapan SMKK Proyek Pembangunan Flyover Sultan Agung

\begin{tabular}{|c|c|c|c|c|}
\hline No & Uraian & $\begin{array}{c}\text { Hasil } \\
\text { Peninjauan }\end{array}$ & Nilai & Keterangan \\
\hline 1 & $\begin{array}{c}\text { Kepemimpinan dan Partisipasi Pekerja Dalam } \\
\text { Keselamatan Konstruksi }\end{array}$ & $83 \%$ & 2 & Cukup Baik \\
\hline 2 & Perencanaan Keselamatan Konstruksi & $100 \%$ & 3 & Sangat Baik \\
\hline 3 & Dukungan Keselamatan Konstruksi & $53 \%$ & 1 & Kurang Baik \\
\hline 4 & Operasi Keselamatan Konstruksi & $55 \%$ & 1 & Kurang Baik \\
\hline 5 & Evaluasi Kinerja Keselamatan Konstruksi & $67 \%$ & 2 & Cukup Baik \\
\hline & Hasil Implementasi & $72 \%$ & 1,8 & Cukup Baik \\
\hline
\end{tabular}

Sumber: Hasil Olahan Pribadi

\section{Analisis Deskriptif Hasil Penelitian}

Secara keseluruhan responden menyetujui bahwa Variabel Kepemimpinan dan Partisipasi Pekerja Dalam Keselamatan
Konstruksi (X1), Variabel Perencanaan Keselamatan Konstruksi (X2), Variabel Dukungan Keselamatan Konstruksi (X3) , Variabel Operasi Keselamatan Konstruksi 
(X4), dan Variabel Evaluasi Kinerja Keselamatan Konstruksi (X5) mempunyai pengaruh dalam implementasi SMKK pada proyek pembangunan Flyover .Hal ini terbukti dengan hasil skor jawaban yang tinggi dengan kategori baik.

Variabel Kinerja Proyek (Y) secara keseluruhan responden menyetujui bahwa variabel tersebut sangat dipengaruhi oleh implementasi SMKK pada proyek Flyover Sultan Agung. Hal ini terbukti dengan hasil skor jawaban yang tinggi yaitu sebesar 3.96 dengan kategori baik.

\section{Uji Kualitas Data}

\section{Uji Validitas}

Uji validitas yang digunakan dalam penelitian ini adalah metode Pearson Product Moment.

Tabel 2: Variabel Kepemimpinan dan Partisipasi Pekerja Dalam Keselamatan Konstruksi (X1)

\begin{tabular}{|c|c|c|c|}
\hline Variabel X1 & \multicolumn{2}{|c|}{ Uji II } & \multirow{2}{*}{$\begin{array}{c}\text { Cronbach's } \\
\text { Alpha } \\
(\alpha)\end{array}$} \\
\hline No Item & $r$ hitung & Ket. & \\
\hline \multicolumn{4}{|l|}{$\mathrm{X} 1.1$} \\
\hline $\mathrm{X} 1.2$ & 0,747 & Valid & \multirow{8}{*}{0.821} \\
\hline $\mathrm{X} 1.3$ & 0,787 & Valid & \\
\hline X1.4 & 0,544 & Valid & \\
\hline $\mathrm{X} 1.5$ & 0,818 & Valid & \\
\hline X1.6 & 0,803 & Valid & \\
\hline $\mathrm{X} 1.7$ & 0,693 & Valid & \\
\hline $\mathrm{X} 1.8$ & 0,427 & Valid & \\
\hline $\mathrm{X} 1.9$ & 0,476 & Valid & \\
\hline X1.10 & & & \\
\hline
\end{tabular}

Tabel 3: Variabel Perencanaan Keselamatan Konstruksi (X2)

\begin{tabular}{|c|c|c|c|}
\hline Variabel X2 & \multicolumn{2}{|c|}{ Uji II } & \multirow{2}{*}{$\begin{array}{c}\text { Cronbach's } \\
\text { Alpha }(\alpha)\end{array}$} \\
\hline No Item & $\mathrm{r}$ hitung & Ket. & \\
\hline $\mathrm{X} 2.1$ & 0,748 & Valid & \multirow{5}{*}{0.860} \\
\hline $\mathrm{X} 2.2$ & 0,817 & Valid & \\
\hline X2.3 & 0,735 & Valid & \\
\hline X2.4 & 0,551 & Valid & \\
\hline $\mathrm{X} 2.5$ & 0,681 & Valid & \\
\hline
\end{tabular}




\begin{tabular}{|c|c|c|c|}
\hline Variabel X2 & \multicolumn{2}{|c|}{ Uji II } & \multirow{5}{*}{$\begin{array}{c}\text { Cronbach's } \\
\text { Alpha (a) }\end{array}$} \\
\hline No Item & $\mathrm{r}$ hitung & Ket. & \\
\hline X2.6 & 0,553 & Valid & \\
\hline X2.7 & 0,755 & Valid & \\
\hline $\mathrm{X} 2.8$ & 0,438 & Valid & \\
\hline X2.9 & & & \\
\hline $\mathrm{X} 2.10$ & & & \\
\hline
\end{tabular}

Tabel 4: Variabel Dukungan Keselamatan Konstruksi (X3)

\begin{tabular}{|c|c|c|c|}
\hline Variabel X3 & \multicolumn{2}{|c|}{ Uji II } & \multirow{2}{*}{$\begin{array}{c}\text { Cronbach's } \\
\text { Alpha } \\
(\boldsymbol{\alpha})\end{array}$} \\
\hline No Item & $\mathrm{r}$ hitung & Ket. & \\
\hline X3.1 & 0,702 & Valid & \multirow{7}{*}{0.886} \\
\hline X3.2 & 0,755 & Valid & \\
\hline X3.3 & 0,753 & Valid & \\
\hline X3.4 & 0,419 & Valid & \\
\hline X3.5 & 0,753 & Valid & \\
\hline X3.6 & 0,620 & Valid & \\
\hline X3.7 & 0,781 & Valid & \\
\hline \multicolumn{4}{|l|}{ X3.8 } \\
\hline X3.9 & 0,537 & Valid & 0.886 \\
\hline X3.10 & & & \\
\hline
\end{tabular}

Tabel 5: Variabel Operasi Keselamatan Konstruksi (X4)

\begin{tabular}{|c|c|c|c|}
\hline Variabel X4 & \multicolumn{2}{|c|}{ Uji II } & \multirow{2}{*}{$\begin{array}{c}\text { Cronbach's } \\
\text { Alpha } \\
(\boldsymbol{\alpha})\end{array}$} \\
\hline No Item & $r$ hitung & Ket. & \\
\hline $\mathrm{X} 4.1$ & 0,783 & Valid & \multirow{2}{*}{0.890} \\
\hline $\mathrm{X} 4.2$ & 0,783 & Valid & \\
\hline $\mathrm{X} 4.3$ & & & \\
\hline $\mathrm{X} 4.4$ & 0,478 & Valid & \multirow{5}{*}{0.890} \\
\hline $\mathrm{X} 4.5$ & 0,704 & Valid & \\
\hline $\mathrm{X} 4.6$ & 0,603 & Valid & \\
\hline $\mathrm{X} 4.7$ & 0,750 & Valid & \\
\hline $\mathrm{X} 4.8$ & 0,478 & Valid & \\
\hline \multicolumn{4}{|l|}{$\mathrm{X} 4.9$} \\
\hline $\mathrm{X} 4.10$ & 0,844 & Valid & 0.890 \\
\hline
\end{tabular}

Tabel 6: Variabel Evaluasi Kinerja Keselamatan Konstruksi (X5)

\begin{tabular}{|c|c|c|c|}
\hline Variabel X5 & \multicolumn{2}{|c|}{ Uji II } & \multirow{2}{*}{$\begin{array}{c}\text { Cronbach's } \\
\text { Alpha } \\
(\boldsymbol{\alpha})\end{array}$} \\
\hline No Item & r hitung & Ket. & \\
\hline X5.1 & 0,761 & Valid & \multirow{6}{*}{0.910} \\
\hline X5.2 & 0,807 & Valid & \\
\hline X5.3 & 0,516 & Valid & \\
\hline X5.4 & 0,681 & Valid & \\
\hline X5.5 & 0,723 & Valid & \\
\hline X5.6 & 0,677 & Valid & \\
\hline
\end{tabular}




\begin{tabular}{|c|c|c|c|}
\hline Variabel X5 & \multicolumn{2}{|c|}{ Uji II } & $\begin{array}{c}\text { Cronbach's } \\
\text { Alpha } \\
(\boldsymbol{\alpha})\end{array}$ \\
\hline No Item & r hitung & Ket. & \\
\hline X5.7 & & & $\mathbf{0 . 9 1 0}$ \\
\hline X5.8 & 0,643 & Valid & \\
\hline X5.9 & & & $\mathbf{0 . 9 1 0}$ \\
\hline X5.10 & 0,809 & Valid & \\
\hline
\end{tabular}

Tabel 7: Variabel Kinerja Proyek (Y)

\begin{tabular}{|c|c|c|c|}
\hline Variabel Y & \multicolumn{2}{|c|}{ Uji I } & \multirow{2}{*}{$\begin{array}{c}\text { Cronbach's } \\
\text { Alpha } \\
(\boldsymbol{\alpha})\end{array}$} \\
\hline No Item & r hitung & Ket. & \\
\hline Y.1 & 0,667 & Valid & \multirow{7}{*}{0.871} \\
\hline Y.2 & 0,559 & Valid & \\
\hline Y.3 & 0,559 & Valid & \\
\hline Y.4 & 0,740 & Valid & \\
\hline Y.5 & 0,755 & Valid & \\
\hline Y.6 & 0,536 & Valid & \\
\hline Y.7 & 0,604 & Valid & \\
\hline Y.8 & 0,701 & Valid & \multirow{5}{*}{0.871} \\
\hline Y.9 & 0,803 & Valid & \\
\hline Y.10 & 0,481 & Valid & \\
\hline Y.11 & 0,803 & Valid & \\
\hline Y.12 & 0,470 & Valid & \\
\hline
\end{tabular}

\section{Analisis Korelasi}

Analisis korelasi merupakan salah satu teknik statistik yang sering dipergunakan untuk mencari hubungan antara dua variabel yaitu variabel terikat dan variabel bebas.

\section{Tabel 8: Korelasi Hubungan Variabel X dan Y}

\begin{tabular}{|c|r|r|c|}
\hline Variabel & $\begin{array}{c}\text { Sig } \\
(2-\text { tailed })\end{array}$ & $\begin{array}{c}\text { Koefisien } \\
\text { Korelasi }\end{array}$ & Keterangan \\
\hline $\mathrm{X} 1$ & .000 &, $759^{* *}$ & Kuat \\
\hline $\mathrm{X} 2$ & .000 &, $830^{* *}$ & Sangat Kuat \\
\hline $\mathrm{X} 3$ & .000 &, $685^{* *}$ & Kuat \\
\hline $\mathrm{X} 4$ & .000 &, $860^{* *}$ & Sangat Kuat \\
\hline $\mathrm{X} 5$ & .000 &, $624^{* *}$ & Kuat \\
\hline
\end{tabular}

Dari hasil analisis korelasi diperoleh hasil bahwa semua variabel menunjukkan hubungan yang berada dalam kategori sangat tinggi dengan nilai signifikansi lebih kecil dari $5 \%(0,000<0,050)$, sehingga dapat disimpulkan bahwa hubungan antara dua variabel $\mathrm{X}$ dan $\mathrm{Y}$ cukup erat.
Analisis Regresi Linier Berganda dan Pembentukan Model

Selanjutnya variabel yang berkorelasi tersebut digunakan untuk melakukan analisis regresi linier berganda. Dari hasil analisis regresi linier berganda tersebut diambil nilai Rsquare terbesar dari kombinasi 5 variabel $\mathrm{X}$ dengan 
variabel Y. Analisis regresi linear berganda dilakukan dengan metode stepwise.

Dari hasil nilai Rsquare (koefisien determinasi) yang sangat besar yaitu sebesar 0.810 atau $81,0 \%$, yang artinya bahwa variabel $\mathrm{X} 1, \mathrm{X} 2, \mathrm{X} 3, \mathrm{X} 4$ dan $\mathrm{X} 5$ secara simultan (bersama-sama) berpengaruh terhadap variabel kinerja proyek (Y) sebesar $81,0 \%$, sisanya sebesar $19 \%$ dipengaruhi oleh variabel lain diluar persamaan regresi ini atau variabel yang tidak diteliti. Selanjutnya didapat output hasil perhitungan regresi linier sebagai berikut:

Tabel 9: Model Summary Hasil Uji Metode Stepwise

\begin{tabular}{|c|c|c|c|c|}
\hline Model & R & R Square & Adjusted R Square & $\begin{array}{c}\text { Std. Error of the } \\
\text { Estimate }\end{array}$ \\
\hline 1 &, $860^{\mathrm{a}}$ &, 740 &, 731 & 2,742 \\
\hline 2 &, $900^{\mathrm{b}}$ &, 810 &, 796 & 2,385 \\
\hline
\end{tabular}

Tabel 10: Koefisien Model (Pengujian Hipotesis Parsial (Uji-t))

\begin{tabular}{|c|c|c|c|c|c|c|}
\hline & \multirow[t]{2}{*}{ Model } & \multicolumn{2}{|c|}{$\begin{array}{c}\text { Unstandardized } \\
\text { Coefficients }\end{array}$} & \multirow{2}{*}{$\begin{array}{c}\text { Standardized } \\
\text { Coefficients } \\
\text { Beta }\end{array}$} & \multirow[t]{2}{*}{$\mathrm{t}$} & \multirow[t]{2}{*}{ Sig. } \\
\hline & & $\mathrm{B}$ & Std. Error & & & \\
\hline \multirow{2}{*}{1} & (Constant) & 9,890 & 4,243 & & 2,331 &, 027 \\
\hline & $\mathrm{X} 4$ & 1,125 &, 126 &, 860 & 8,927 &, 000 \\
\hline \multirow{3}{*}{2} & (Constant) & 11,409 & 3,722 & & 3,065 &, 005 \\
\hline & $\mathrm{X} 4$ & 1,749 &, 226 & 1,338 & 7,743 &, 000 \\
\hline & $\mathrm{X} 5$ &, 621 & ,197 &, 546 & 3,161 &, 004 \\
\hline
\end{tabular}

Dari hasil analisis regresi linier berganda menghasilkan 2 (dua) variabel yang dominan, yaitu variabel X4 dan X5.Variabel-variabel tersebut terpilih menjadi variabel dominan dari 5 variabel $X$ yang ada, yang berarti bahwa variabel X4 dan X5 merupakan variabel paling berpengaruh terhadap variable Y (kinerja proyek pembangunan flyover).

Berikut model persamaan regresi linear berganda dari hasil output perhitungan diatas : $Y=11,409+1.749 X 4+0.621$ X5

Dimana:

$\mathrm{Y}=$ Kinerja Proyek

$\mathrm{X} 4=$ Operasi Keselamatan Konstruksi

\section{X5 = Evaluasi Kinerja Keselamatan Konstruksi}

\section{Uji Asumsi Klasik}

Uji asumsi klasik dilakukan agar model yang terbentuk memberikan estimasi yang BLUE (Best, Linear, Unbiased, Estimator).Pengujian asumsi klasik ini terdiri atas tiga pengujian, yakni uji normalitas, uji mutikolinieritas, dan uji heteroskedastisitas [6].

\section{Uji Normalitas}

Berdasarkan hasil pengujian diketahui nilai Kolmogorov-Smirnov $Z$ sebesar 0.152 dengan asymp sig sebesar 0. 076. (0.076> 0.05). 
Sehingga dapat diambil kesimpulan data terdistribusi secara normal dengan kata lain model regresi linier berganda memiliki distribusi yang normal.

Tabel 11: Hasil Uji Normalitas

\begin{tabular}{|c|c|c|}
\hline \multicolumn{3}{|c|}{ One-Sample Kolmogorov-Smirnov Test } \\
\hline & & $\begin{array}{c}\text { Unstandardized } \\
\text { Residual }\end{array}$ \\
\hline \multicolumn{2}{|l|}{$\mathrm{N}$} & 30 \\
\hline \multirow{2}{*}{ Normal Parameters $\mathrm{a}, \mathrm{b}$} & Mean &, 0000000 \\
\hline & Std. Deviation & 2,30165106 \\
\hline \multirow[t]{3}{*}{ Most Extreme Differences } & Absolute & , 152 \\
\hline & Positive &, 152 \\
\hline & Negative &,- 107 \\
\hline \multicolumn{2}{|l|}{ Test Statistic } &, 152 \\
\hline \multicolumn{2}{|l|}{ Asymp. Sig. (2-tailed) } & $076^{\mathrm{c}}$ \\
\hline \multicolumn{3}{|l|}{ a. Test distribution is Normal. } \\
\hline \multicolumn{3}{|c|}{ b. Calculated from data. } \\
\hline \multicolumn{3}{|c|}{ c. Lilliefors Significance Correction. } \\
\hline
\end{tabular}

\section{Uji Multikolinieritas}

Tabel 12: Nilai VIF Uji Multikolinieritas

\begin{tabular}{|c|r|c|c|}
\hline \multicolumn{4}{|c|}{ Coefficients $^{\text {a }}$} \\
\hline \multirow{2}{*}{ Model } & \multicolumn{2}{|c|}{ Collinearity Statistics } \\
\cline { 2 - 4 } \multicolumn{2}{|c|}{ Tolerance } & VIF \\
\hline \multirow{2}{*}{2} & & & \\
\cline { 2 - 4 } 2 & $\mathrm{X} 4$ & .236 & 4,246 \\
\cline { 2 - 4 } & $\mathrm{X} 5$ & .236 & 4,246 \\
\hline \multicolumn{4}{|c|}{ a. Dependent Variable: $\mathrm{Y}$} \\
\hline
\end{tabular}

Hasil pada Tabel 12 menunjukkan bahwa nilai

VIF masing-masing variabel bebas dibawah 10, serta nilai tolerance kedua variabel memiliki nilai di atas 0.1. Sehingga disimpulkan bahwa tidak terdapat multikolinieritas antar variabel bebas dalam model.

\section{Uji Heteroskedastisitas}

Dari Grafik output hasil uji heteroskedastisitas dengan pola gambar scatterplots, dapat dilihat bahwa : titik-titik data menyebar diatas dan dibawa atau disekitar angka 0 , penyebaran titik-titk data tidak membentuk pola bergelombang melebar kemudian menyempit dan melebar kembali, penyebaran titik-titik data tidak berpola. Dengan demikian dapat diambil kesimpulan bahwa pada model regresi berganda tidak terjadi gejala heteroskedastisitas, sehingga model regresi berganda yang baik dan ideal dapat terpenuhi. 


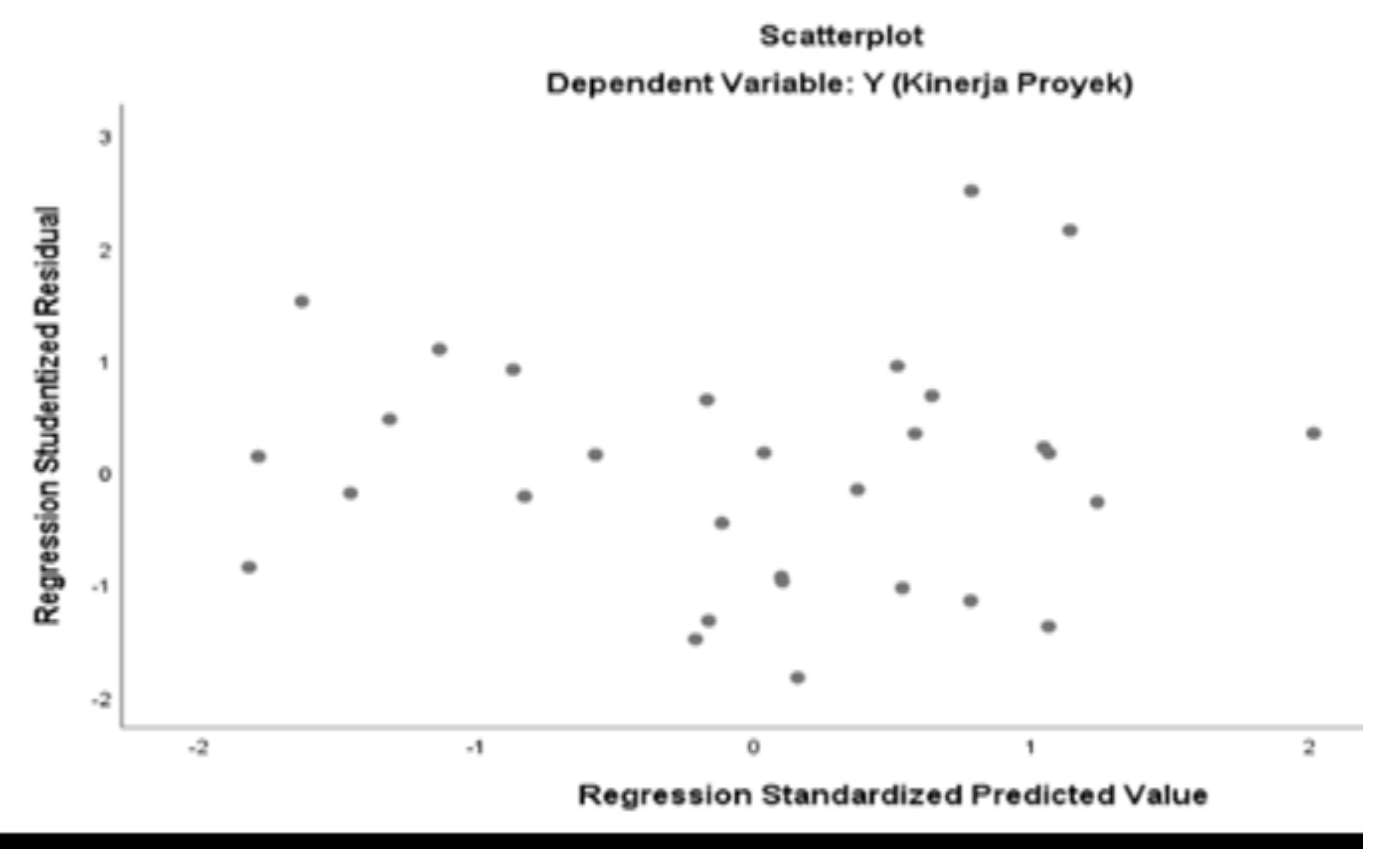

Gambar 1: Grafik Scatterplot

\section{Pengujian Hipotesis}

Uji F

Pengujian hipotesis secara simultan (uji F) bertujuan untuk mengetahui apakah secara bersama-sama variabel bebas (independen) berpengaruh signifikan atau tidak berpengaruh signifikan terhadap variabel terikat (dependen).

Dari hasil perhitungan diperoleh nilai Fhitung sebesar 57.633. Nilai F pada Tabel distribusi F. Untuk $\alpha=5 \%, d f_{1}=k=2$, dan $d f_{2}=n-k-1$ $=30-2-1=27$ diperoleh nilai $F_{\text {Tabel }}$ $=$ sebesar 3.354 .

Kriteria uji hipotesis sebagai berikut:

Jika $\mathrm{F}_{\text {hitung }}>\mathrm{F}_{\text {Tabel }}$ maka $\mathrm{H}_{0}$ ditolak dan $\mathrm{H}_{1}$ diterima.

Jika $\mathrm{F}_{\text {hitung }}<\mathrm{F}_{\text {Tabel }}$ maka $\mathrm{H}_{0}$ ditolak dan $\mathrm{H}_{1}$ ditolak.
Dari hasil penelitian dapat diketahui bahwa $F_{\text {hitung }}(57.633)>\mathrm{F}_{\text {Tabel }}$ (3.354), maka $\mathrm{H} 1$ diterima.

Sehingga dapat disimpulkan bahwa secara simultan (secara bersama-sama) Variabel X4 (Operasi Keselamatan Konstruksi), dan Variabel X5 (Evaluasi Kinerja Keselamatan Konstruksi) berpengaruh signifikan terhadap Variabel Y (Kinerja Proyek).Artinya, terdapat hubungan linier antara faktor-faktor dominan Implementasi Sistem Manajemen Keselamatan Konstruksi terhadap Kinerja Proyek, sehingga hipotesa penelitian dapat dinyatakan layak dan terbukti. 
Tabel 13: Tabel Anova

\begin{tabular}{|c|c|c|c|c|c|c|}
\hline \multicolumn{7}{|c|}{${ }^{A N O V A}{ }^{a}$} \\
\hline \multicolumn{2}{|c|}{ Model } & Sum of Squares & $\mathrm{df}$ & Mean Square & $\mathrm{F}$ & Sig. \\
\hline \multirow[t]{3}{*}{1} & Regression & 599,020 & 1 & 599,020 & 79,687 & $\mathrm{O} O \mathrm{Ob}$ \\
\hline & Residual & 210,480 & 28 & 7,517 & & \\
\hline & Total & 809,500 & 29 & & & \\
\hline \multirow[t]{3}{*}{2} & Regression & 655,870 & 2 & 327,935 & 57,633 & $00 \Omega^{c}$ \\
\hline & Residual & 153,630 & 27 & 5,690 & & \\
\hline & Total & 809,500 & 29 & & & \\
\hline \multicolumn{7}{|c|}{ a. Dependent Variable: Y (Kinerja Proyek) } \\
\hline \multicolumn{7}{|c|}{ b. Predictors: (Constant), X4 } \\
\hline \multicolumn{7}{|c|}{ c. Predictors: (Constant), X4, X5 } \\
\hline
\end{tabular}

\section{Uji T}

Tabel 14 : Pengujian Hipotesis Parsial (Uji T)

\begin{tabular}{|c|c|c|c|c|c|c|c|c|c|c|c|}
\hline & \multicolumn{11}{|c|}{ Coefficients $\mathbf{a}^{\mathrm{a}}$} \\
\hline & \multirow[b]{2}{*}{ Model } & \multicolumn{2}{|c|}{$\begin{array}{c}\text { Unstandardized } \\
\text { Coefficients }\end{array}$} & \multirow{2}{*}{\begin{tabular}{|c}
$\begin{array}{c}\text { Standardized } \\
\text { Coefficients }\end{array}$ \\
Beta
\end{tabular}} & \multirow[t]{2}{*}{ שת שس } & \multirow[b]{2}{*}{ Sig. } & \multicolumn{3}{|c|}{ Correlations } & \multicolumn{2}{|c|}{$\begin{array}{c}\text { Collinearity } \\
\text { Statistics }\end{array}$} \\
\hline & & B & $\begin{array}{c}\text { Std. } \\
\text { Error }\end{array}$ & & & & $\begin{array}{l}\text { Zero- } \\
\text { order }\end{array}$ & Partial & Part & Tolerance & VIF \\
\hline \multirow[t]{2}{*}{1} & (Constant) & 9,890 & 4,243 & & 2,331 & ,027 & & & & & \\
\hline & $\mathrm{X} 4$ & 1,125 &, 126 & ,860 & 8,927 & ,000 & ,860 & ,860 & ,860 & 1,000 & 1,000 \\
\hline \multirow[t]{3}{*}{2} & (Constant) & 11,409 & 3,722 & & 3,065 & ,005 & & & & & \\
\hline & $\mathrm{X} 4$ & 1,749 & ,226 & 1,338 & 7,743 & ,000 & ,860 & ,830 & ,649 & ,236 & 4,246 \\
\hline & $\mathrm{X} 5$ &, 621 &, 197 &, 546 & 3,161 &, 004 & ,624 &, 520 &, 265 & ,236 & 4,246 \\
\hline
\end{tabular}

Pengujian hipotesis secara parsial (uji $\mathrm{T}$ ) bertujuan untuk mengetahui apakah secara parsial variabel bebas (independen) berpengaruh signifikan atau tidak berpengaruh signifikan terhadap variabel terikat (dependen). Hasil perhitungan pengujian parsial adalah sebagai berikut: Berdasarkan Tabel 14 diperoleh nilai thitung untuk variabel X4 sebesar 7.743, dan X5 sebesar 3,161. Nilai-nilai thitung tersebut

kemudian dibandingkan dengan nilai t pada Tabel distribusi t. Dengan $\alpha=5 \%$ dan $d f=n$ $k-1=30-2-1=27$ diperoleh nilai $t_{\text {tabel }}$ dari Tabel distribusi t untuk pengujian dua pihak sebesar 2.052 .
Statistik uji :

Uji t pada taraf signifikansi $(\alpha)=5 \%$.

Kriteria yang digunakan adalah sebagai berikut:

Tolak $\mathrm{H}_{0}$ dan terima $\mathrm{H}_{1}$ jika $\mathrm{t}_{\text {hitung }} \geq \mathrm{t}_{\text {tabel}}$; atau

Terima $\mathrm{H}_{0}$ dan tolak $\mathrm{H}_{1}$ jika $\mathrm{t}_{\text {hitung }}<\mathrm{t}_{\text {tabel. }}$. Berdasarkan hasil pengujian dapat dilihat nilai $t_{\text {hitung }}$ variabel $\mathrm{X} 4$ sebesar 7,743 dan variabel X5 sebesar 3.161. Karena nilai thitung kedua variabel (7.743 dan 3.161) > tTabel 2.052 maka diputuskan untuk menolak H0 dan menerima H1 . Sehingga dapat disimpulkan bahwa secara parsial variabel X4 (Operasi Keselamatan Konstruksi) dan variabel X5 (Evaluasi Kinerja Keselamatan

Jurnal Techno-Socio Ekonomika, Volume 14 No. 2 Oktober 2021 
Konstruksi) berpengaruh signifikan terhadap variabel Y (Kinerja Proyek).

\section{Pembuktian Hipotesa}

Dari hasil olah data yang telah dilakukan, dapat diketahui bahwa hipotesis penelitian sudah dapat dibuktikan. Hasil hipotesis dapat dilihat pada analisis model regresi yang menunjukkan adanya hubungan antara faktor-faktor dominan implementasi Sistim Manajemen Keselamatan Konstruksi (SMKK) terhadap Kinerja Proyek telah dinyatakan valid setelah dilakukan uji model. Hipotesa penelitian tersebut menyatakan bahwa: "Terdapat pengaruh faktor-faktor dominan Implementasi Sistem Manajemen Keselamatan Konstruksi Terhadap Kinerja Proyek Pembangunan Flyover Sultan Agung". Model yang diperoleh dari hasil analisis regresi adalah :

$Y=11,409+1.749 X 4+0.621 X 5$

Dari hasil analisis tersebut dapat diketahui bahwa terdapat hubungan linear dimana apabila terjadi peningkatan kinerja.

Implementasi Sistem Manajemen

Keselamatan Konstruksi maka akan meningkat pula Kinerja Proyek Pembangunan flyover". Dengan demikian dapat diambil kesimpulan bahwa model yang diperoleh tersebut telah dapat membuktikan hipotesis dari penelitian

\section{KESIMPULAN DAN SARAN}

\section{Kesimpulan}

1. Implementasi Sistem Manajemen Keselamatan Konstruksi (SMKK) pada pelaksanaan proyek pembangunan flyover Sultan Agung telah dilakukan dengan cukup baik. Hasil prosentase penilaian implementasi Sistem Manajemen Keselamatan Konstruksi (SMKK) dan audit internal mencapai angka yang cukup signifikan . Untuk penilaian rencana penerapan Sistem Manajemen Keselamatan Konstruksi (SMKK) diperoleh hasil prosentase 72\%, sebaliknya komponen kegiatan pelaksanaan Sistem Manajemen Keselamatan Konstruksi (SMKK) telah dilaksanakan secara menyeluruh.

2. Hasil output dari analisis regresi linier berganda mengeluarkan 2 variabel independent sebagai faktor dominan implementasi Sistem Manajemen Keselamatan Konstruksi yang berpengaruh terhadap kinerja proyek pelaksanaan proyek pembangunan flyover yaitu : Variabel X4 (Operasi Keselamatan Konstruksi) dan Variabel X5 (Evaluasi Kinerja Keselamatan Konstruksi).

3. Besar pengaruh faktor-faktor dominan implementasi Sistem Manajemen Keselamatan Konstruksi (SMKK) terhadap Kinerja Proyek yang diukur dalam parameter efisiensi waktu, efisiensi biaya dan kualitas hasil kerja adalah : 
a. Faktor Operasi Keselamatan Konstruksi (X4) adalah berpengaruh secara signifikan dengan nilai $t_{\text {hitung }}$ $7,743>t_{\text {tabel }} 2.052($ Sig. $\alpha<5 \%)$.

b. Faktor Evaluasi Kinerja Keselamatan Konstruksi (X5) adalah berpengaruh secara signifikan dengan nilai $\mathrm{t}_{\text {hitung }}$ $3.161>t_{\text {tabel }} 2.052($ Sig. $\alpha<5 \%)$.

4. Besar korelasi antara faktor-faktor implementasi Sistim Manajemen Keselamatan Konstruksi (SMKK) terhadap Kinerja Proyek Pembangunan Flyover memiliki hubungan yang signifikan dengan hasil sebagai berikut:

- Korelasi antara faktor Kepemimpinan dan Partisipasi Pekerja Dalam Keselamatan Konstruksi (X1) sebesar $0,759>0,6$ (kuat).

- Korelasi antara

faktor

Perencanaan

Keselamatan

Konstruksi

(X2) sebesar $0,830>$

0,6 (sangat kuat).

- Korelasi antara

faktor

Dukungan Keselamatan Konstruksi (X3) sebesar 0,685 > 0,6 (kuat).

- Korelasi antara

faktor

Operasi Keselamatan Konstruksi (X4) sebesar 0,860 > 0,6 (sangat kuat).

- Korelasi antara faktor Evaluasi Kinerja Keselamatan Konstruksi sebesar 0,624 > 0,6 (kuat).

\section{Saran}

Berdasarkan hasil penelitian dan kesimpulan yang telah diuraikan diatas, maka saran-saran yang dapat diberikan :

1. Perlu sosialisasi, penyuluhan dan pelatihan yang lebih mendalam mengenai implementasi SMKK di lapangan guna menghindari kecelakaan kerja akibat kelalaian ketidakdisiplinan para pekerja dan pihak manajemen dalam penggunaan APD dan APK.

2. Pemberian penghargaan kepada para pekerja proyek dan pihak manajemen dalam hal penggunaan APD dan APK serta ketaatan dalam mematuhi peraturan K3 Konstruksi di lapangan guna memacu implementasi SMKK secara maksimal.

3. Untuk penelitian lebih lanjut mengenai SMKK perlu dilakukan studi kasus yang lebih mendalam mengenai implementasi pelaksanaan SMKK di lapangan. Jumlah responden yang lebih banyak, jenis konstruksi yang lebih beragam, serta metode penilaian yang lebih objektif sehingga diharapkan dapat lebih menambah keakuratan data penelitian.

\section{DAFTAR PUSTAKA}

[1] Analisa Risiko Kecelakaan Kerja Pada Proyek Konstruksi Jembatan Musi VI Palembang.Diakses pada 25 Januari 2020, dari https://anggiyuli13.blogspot. com.

[2] Tamin, R. Z., dan Tim Penyusun. (2013)." Konstruksi Indonesia 2013", Kementrian Pekerjaan Umum. 
[3] Peraturan Menteri Pekerjaan Umum dan Perumahan Rakyat Nomor 21 Tahun 2019 tentang "Pedoman Sistem Manajemen Keselamatan Konstruksi”.

[4] Modul 3 Pengetahuan Dasar Keselama tan Konstruksi Pelatihan Sistem Manajemen Keselamatan Konstruksi (SMKK). Diakses pada 25 Januari 2020,darihttps://simantu.pu.go.id/epel/e dok/fc523.

[5] Yulindasari, Harti dan Hendri Soekotjo.(2018)." Pengaruh Keputusan Investasi, Keputusan Pendanaan, Dan
Kebijakan Dividen Terhadap Return Saham Pada Perusahaan Investasi", Jurnal Ilmu dan Riset Manajemen, Volume 7, Nomor 6.

[6] Y, Maria, Aryati Wahyuningrum. Pengaruh Kualitas Produk, Citra Merek, Dan Word Of Mouth Terhadap Keputusan Pembelian Bolu Susu Lembang. Diakses pada 01 Februari 2020, dari http://yosephine.staff.gunadarma.ac.id/ D 